
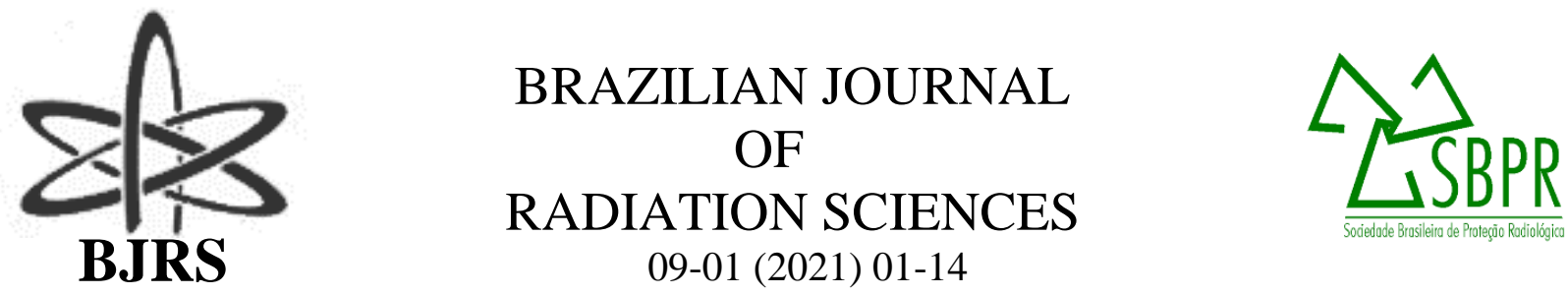

\title{
Production of High Purity Samarium Acetate for Use in Nuclear Area
}

\author{
Carlos Alberto da Silva Queiroz ${ }^{1}$ and Walter dos Reis Pedreira Filho ${ }^{2}$ \\ ${ }^{1}$ Instituto de Pesquisas Energéticas e Nucleares - Comissão Nacional de Energia \\ Nuclear Av. Professor Lineu Prestes 2242 \\ 05508-000 São Paulo, SP, Brasil cqueiroz@ipen.br \\ ${ }^{2}$ FUNDACENTRO
}
Rua Capote Valente 710, Pinheiros, 05409-002, SP, SP, Brasil
walter.pedreira@fundacentro.gov.br

\begin{abstract}
Samarium is currently used in many applications, such as catalysts, lasers and metal alloys. Samarium is also employed to absorb neutrons in nuclear reactors. In medicine, samarium is used in the form of radioactive ${ }^{153} \mathrm{Sm}$ to produce radiopharmaceuticals. A simple process for the preparation of pure samarium acetate was studied. The raw material, which was used in the form of rare earth carbonates was produced industrially from the chemical treatment of Brazilian monazite. Ion exchange chromatography was performed using a strong cationic resin to fractionate rare earth elements (REE). Under these conditions, 99.9\% pure $\mathrm{Sm}_{2} \mathrm{O}_{3}$ and yield greater than or equal 60\% was eluted by ammonium salt of ethylenediaminetetraacetic acid (EDTA) solution in controlled pH. The EDTA-samarium complex was transformed into samarium oxide, which was subsequently dissolved in acetic acid to obtain the samarium acetate. Molecular absorption spectrophotometry was used to monitor the samarium and sector field inductively coupled plasma mass spectrometry was used to certify the purity of the samarium acetate. The solid salt was characterized by chemical analysis, thermal analysis, infrared spectroscopy and $X$ ray diffraction. The analytical data collected allowed to conclude that stoichiometric formula for the samarium acetate obtained is $\mathrm{Sm}\left(\mathrm{CH}_{3} \mathrm{COO}\right)_{3} \cdot 4 . \mathrm{H}_{2} \mathrm{O}$.
\end{abstract}

Keywords: Samarium, Ion exchange, Rare Earth. 


\section{INTRODUCTION}

The extraction of rare earths in Brazil occurs during the industrial exploitation of monazite. Herein, we use mixed rare earth (RE) carbonates depleted in cerium and lanthanum from the monazite processing industry to obtain high-purity $\mathrm{Sm}_{2} \mathrm{O}_{3}$ by ion exchange chromatography. Monazite is a heavy mineral composed of RE phosphates and thorium. Monazite occurs as an accessory constituent to granites, gneisses and pegmatites, as well as sands from the decomposition of the afore-mentioned rocks [1].

In Brazil, monazite is found in riverbeds located in Bahia, Minas Gerais, Goias and Mato Grosso, and the beaches off the coast of Bahia, Espirito Santo and Rio de Janeiro, which contain $25 \%$ to $30 \%$ of monazite. Other minerals present in monazite include quartz, zircon, ilmenite, magnetite and rutile [2-4].

The present procedure for the separation of samarium was carried out using raw material from the separation of thorium and rare earths in monazite. Fractional precipitation and ion exchange chromatography were employed to obtain high-purity samarium oxide. Molecular absorption spectrophotometry and Inductively Coupled Plasma Mass Spectrometry (ICP- MS) were used to ensure the quality of the samarium oxide and samarium acetates, respectively. At IPENCNEN/SP, the separation of rare-earth metals is performed to meet internal demands in other research areas [5-18].

\section{MATERIALS AND METHODS}

\subsection{Starting Raw Materials}

A representative aliquot of commercial rare earth (RE) carbonates (17\% Sm2O3) was used. Hydrochloric acid, acetic acid, the ammonium salt of ethylene-diamine-tetra acetic acid (EDTA) and all other reagents were of analytical grade. Solutions of RE chlorides were prepared by dissolving the RE carbonates in hydro-chloric acid. Solutions of RE chlorides with a RE2O3 concentration of $10 \mathrm{~g} \mathrm{~L}-1$ were filtered to remove insoluble products. 


\subsection{Loading the Resin and Eluting the Rare Earth Metals to Obtain 20-93\% purity}

\section{Sm2O3. Ion Exchange 1 - Stage 1}

Rare earth chlorides solution with a concentration of $10 \mathrm{~g} \mathrm{~L}-1$ in mixed rare earth oxides were pumped into a system of columns filled with a strong cationic resin, which is typically used as a resin for water treatment and that is easy to obtain in the Brazilian market. The resin was rinsed with deionized water subsequently. REEs in the resin were eluted with EDTA solution at pH 3.54.0. The effluent was collected in fractions, from which the oxalates were precipitated and converted into oxides. Ion exchange-system-1 contained several columns connected in series, including 3 columns with a length of 1.4 meters and a diameter of $12 \mathrm{~cm}$ and 4 columns with a length of 1.0 meter each and a diameter of $5 \mathrm{~cm}$. In this way, samarium oxide with a purity of $20 \%$ to $93 \%$ was obtained.

\subsection{Loading the Resin and Eluting the REEs to Obtain $\geq 99.9 \%$ purity Sm2O3. Ion Ex-} change 2 - Stage 2

Several fractions (20\%-93\%) were combined to obtain $200 \mathrm{~g}$ of oxide yield a $65 \%$ Sm2O3 concentrate, and the combined fractions were dissolved in hot 1:1 $\mathrm{HCl}$. The resulting solution was diluted to $10 \mathrm{~g} \mathrm{~L}-1$ of $65 \% \mathrm{Sm} 2 \mathrm{O} 3$. This solution was percolated subsequently in another ion exchange - system 2 containing 5 columns with length 1 meter and a diameter of $5 \mathrm{~cm}$, which were connected in series and filled with a strong cationic resin. The same resin used in the previous section was employed in the second ion exchange system, and an EDTA solution at pH 3.5-4.0 was used to elute the REEs. As a result, $\mathrm{Sm} 2 \mathrm{O} 3$ with a purity $\geq 99.9 \%$ was obtained. A block diagram of this process is presented in Figure 1.

\subsection{High Purity Samarium Acetate - Stage 3}

For the preparation of highly pure samarium acetate, samarium oxide with a purity $\geq 99.9 \%$ was obtained using the procedure previously described. In the experimental procedure samarium oxide was added to acetic acid and the resulting solution was heated to evaporate excess acid. The formation of samarium acetate crystals was achieved subsequently. The resulting material was characterized by SF ICP-MS to determine the quality of the samarium acetate. 


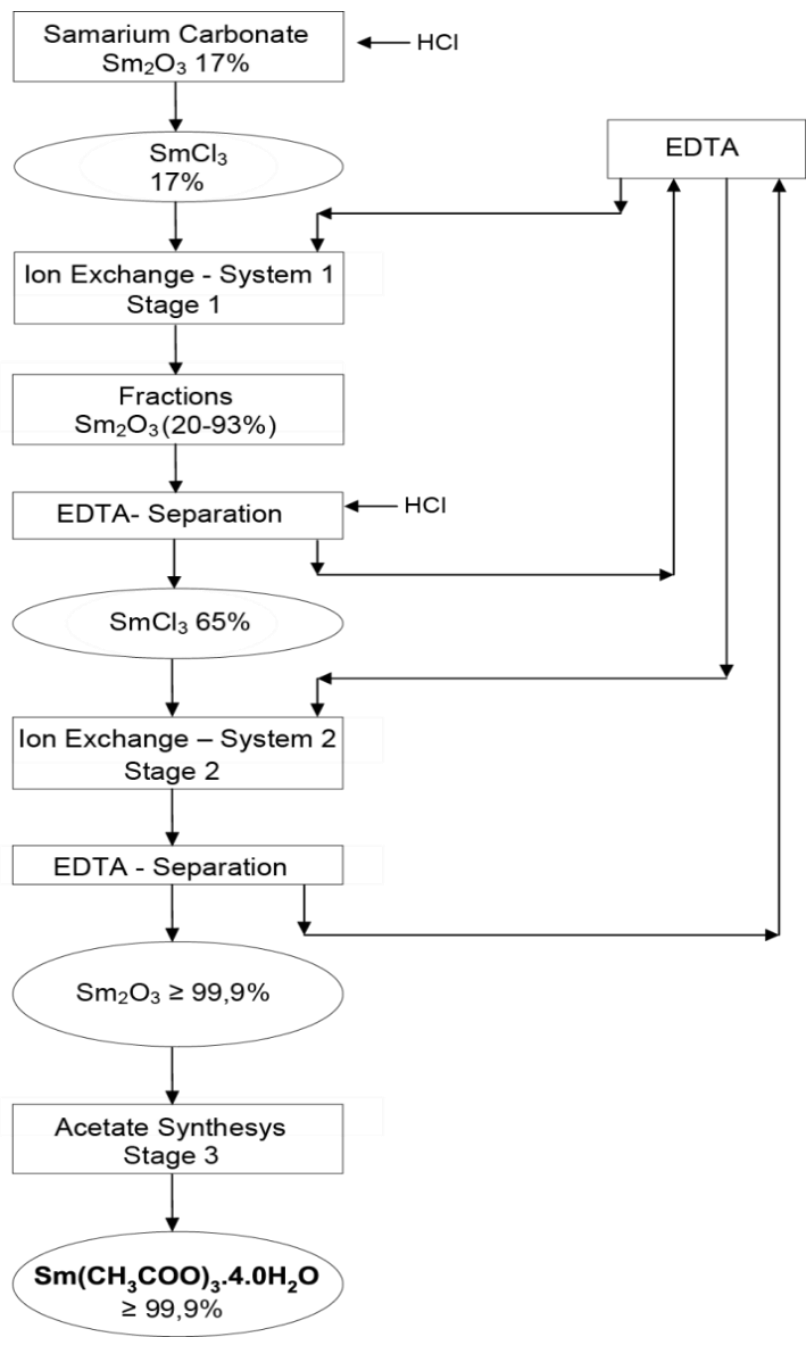

Figure 1: Procedure used for the preparation of pure samarium acetate

\section{RESULTS AND DISCUSSION}

Table 1 shows the elution conditions and mass balance in enriched samarium from RE carbonates $\left(17 \% \mathrm{Sm}_{2} \mathrm{O}_{3}\right)$ using ion exchange-system 1- stage 1. Various fractions with a samarium oxide content between $20 \%$ and $93 \% \mathrm{Sm}_{2} \mathrm{O}_{3}$ were obtained. Several fractions were combined to obtain a $65 \% \mathrm{Sm}_{2} \mathrm{O}_{3}$ concentrate, which was used in ion exchange-system 2 - stage 2 to increase the purity to $\geq 99 \% \mathrm{Sm}_{2} \mathrm{O}_{3}$, see Table 2 . 
Table 1: Ion exchange - system 1 (stage 1). Elution and mass balance of enriched samarium from mixed rare earth carbonates $\left(17 \% \mathrm{sm}_{2} \mathrm{O}_{3}\right)$. Eluent: edtasolution- acetic acid-nh $4 \mathrm{oh}$ at ph 3.5-4.0.

Elution rate: $8 \pm 2 \mathrm{ml} /$ minute. Analyzed by spectrophotometry $(399.5 \mathrm{~nm})$

\begin{tabular}{cccccc}
\hline Fraction & $\mathrm{pH}$ & $\begin{array}{c}\text { Time } \\
(\mathrm{h})\end{array}$ & $\begin{array}{c}\text { Oxide } \\
(\mathrm{g})\end{array}$ & $\begin{array}{c}\text { Oxide } \\
\text { Color }\end{array}$ & $\begin{array}{c}\mathrm{Sm}_{2} \mathrm{O}_{3} \\
(\%)\end{array}$ \\
\hline 1 & 3.5 & 583 & 623 & - & - \\
2 & 4.0 & 30 & 30 & White & - \\
3 & 4.0 & 24 & 14 & White & 20 \\
4 & 4.0 & 48 & 30 & Yellow & 26 \\
5 & 4.0 & 96 & 88 & Yellow & 35 \\
6 & 4.0 & 24 & 30 & Yellow & 45 \\
7 & 4.0 & 24 & 27 & Yellow & 60 \\
8 & 4.0 & 48 & 46 & Yellow & 76 \\
9 & 4.0 & 24 & 31 & Yellow & 93.5 \\
10 & 4.0 & 48 & 50 & Yellow & 93 \\
11 & 4.0 & 24 & 30 & Yellow & 93.4 \\
12 & 4.0 & 48 & 42 & Yellow & 93 \\
13 & 4.0 & 96 & 121 & Brown & 72 \\
\hline
\end{tabular}

The REE impurities content in samarium acetate prepared ( $\geq 99,9 \%)$ in stage 3 is shown in Table 3 and Table 4.

\subsection{Characterization of the samarium acetate (stage 3 )}

\subsubsection{Elemental analysis}

The carbon and hydrogen content in the samarium acetate samples was determined by an element analyzer $(\mathrm{CH})$ using the equipment Elemental Analyzer-2400, Perkin Elmer. Table V shows the values to $\mathrm{C}$ and $\mathrm{H}$. Samarium was determined by gravimetric analyses and thermal analyzes (Fig. 2).

The percent of $\mathrm{H}_{2} \mathrm{O}$ calculated and experimentally obtained for the samarium acetate hydrate prepared here come from the TG and DTG analyzes, see Table VI and Figure 2. 


\subsection{Thermal characterization (TG/DTG) of prepared samarium acetate}

Samples of highly pure samarium acetate were submitted to thermal analysis for their characterization. The equipment used it was a Mettler-Toledo TGA/SDTA 851. The samples were analyzed under dynamic atmosphere of nitrogen with a flow of $50 \mathrm{ml} / \mathrm{min}$ and heating rate of $1000 \mathrm{C} / \mathrm{min}$ and the temperature program rate from $2500 \mathrm{C}$ to $9000 \mathrm{C}$, see Figure 2.

\subsection{X-Ray analyze of the prepared samarium acetate}

The equipment used it was a Philips PW - 1710 diffractometer. The interpretation of the results was made using the standard pattern of the JCPDS data bank. The graphic obtained is presented in Figure 3.

\subsection{Infrared spectroscopy (ir) of the prepared samarium acetate}

The absorption spectrum in the infrared region was recorded in the range 4000 to $400 \mathrm{~cm}-1$. The samarium acetate sample was mixed in $\mathrm{KBr}$ and pressed into pellet form. The equipment used was the spectrophotometer model FTIR 670 Nexus, Nicolet. See Figure 4. 
Table 2: Ion exchange - system 2 - stage 2. Elution and mass balance of enriched samarium from mixed rare earth chlorides (mixed oxides: $200 \mathrm{~g}$ ) $65 \% \mathrm{sm}_{2} \mathrm{O}_{3}$. Eluent: edta solution with acetic acid $1 \%$ (viv) at ph 3.5. Elution rate: $6 \pm 2 \mathrm{ml} /$ minute. Analyzed by spectrophotometry $(399.5 \mathrm{~nm})$.

\begin{tabular}{|c|c|c|c|}
\hline Fraction & $\begin{array}{c}\text { Time } \\
\text { (h) }\end{array}$ & $\begin{array}{c}\text { Oxides } \\
(\mathrm{g})\end{array}$ & $\begin{array}{c}\mathrm{Sm}_{2} \mathrm{O}_{3} \\
(\%)\end{array}$ \\
\hline 1 & 456 & 37.02 & 59,32 \\
\hline 2 & 24 & 2.56 & 70.37 \\
\hline 3 & 40 & 4.0 & 87.03 \\
\hline 4 & 72 & 8.5 & 95 \\
\hline 5 & 24 & 3.1 & $\geq 99$ \\
\hline 6 & 24 & 3.0 & $\geq 99$ \\
\hline 7 & 24 & 3.5 & $\geq 99$ \\
\hline 8 & 24 & 3.5 & $\geq 99$ \\
\hline 9 & 72 & 8.6 & $\geq 99$ \\
\hline 10 & 24 & 3.0 & $\geq 99$ \\
\hline 11 & 24 & 3.0 & $\geq 99$ \\
\hline 12 & 24 & 3.0 & $\geq 99$ \\
\hline 13 & 24 & 4.2 & $\geq 99$ \\
\hline 14 & 72 & 8.1 & $\geq 99$ \\
\hline 15 & 24 & 4.3 & $\geq 99$ \\
\hline 16 & 72 & 14.1 & $\geq 99$ \\
\hline 17 & 72 & 10 & $\geq 99$ \\
\hline 18 & 72 & 9.9 & $\geq 99$ \\
\hline 19 & 72 & 11.7 & $\geq 99$ \\
\hline 20 & 96 & 15.2 & $\geq 99$ \\
\hline 21 & 72 & 10 & 80 \\
\hline 22 & 96 & 11 & 50 \\
\hline
\end{tabular}


Table 3: Stage 3 - Rare earth impurities present in samarium acetate prepared. Inductively Coupled Plasma Mass Spectrometry (ICP-MS) [14]

\begin{tabular}{cc} 
Element & $\begin{array}{c}\mathrm{Sm}\left(\mathrm{CH}_{3} \mathrm{COO}\right)_{3} .4 \mathrm{H}_{2} \mathrm{O} \\
\left(\mu \mathrm{g}-\mathrm{g}^{-1}+/-\sigma\right)\end{array}$ \\
$\mathrm{Y}$ & $11.80+/-0.20$ \\
$\mathrm{Sc}$ & $20.90+/-0.22$ \\
$\mathrm{La}$ & $3.36+/-0.81$ \\
$\mathrm{Ce}$ & $1.87+/-0.70$ \\
$\mathrm{Pr}$ & $1.28+/-0.80$ \\
$\mathrm{Nd}$ & $2.98+/-0.80$ \\
$\mathrm{Sm}$ & $\ldots \ldots \ldots \ldots \ldots \ldots$ \\
$\mathrm{Eu}$ & $8.40+/-0.90$ \\
$\mathrm{Gd}$ & $15.40+/-0.40$ \\
$\mathrm{~Tb}$ & $1.41+/-0.50$ \\
$\mathrm{Dy}$ & $1.92+/-0.50$ \\
$\mathrm{Ho}$ & $2.85+/-0.10$ \\
$\mathrm{Er}$ & $1.49+/-0.70$ \\
$\mathrm{Tm}$ & $2.96+/-0.10$ \\
$\mathrm{Yb}$ & $19.90+/-0.60$ \\
\hline
\end{tabular}

Table 4: Metallic impurities $\left(\mu \mathrm{g} . \mathrm{g}^{-1}\right)$ in the high pure samarium acetate prepared Inductively Coupled Plasma Mass Spectrometry (ICP-MS) [14]

\begin{tabular}{cccc}
\hline Element & $\begin{array}{c}\mathrm{Sm}\left(\mathrm{CH}_{3} \mathrm{COO}\right)_{3} \cdot 4 \mathrm{H}_{2} \mathrm{O} \\
\left(\mu \mathrm{g}-\mathrm{g}^{-1}+/-\sigma\right)\end{array}$ & Element & $\begin{array}{c}\mathrm{Sm}\left(\mathrm{CH}_{3} \mathrm{COO}\right)_{3} \cdot 4 \mathrm{H}_{2} \mathrm{O} \\
\left(\mu \mathrm{g}-\mathrm{g}^{-1}+/-\sigma\right)\end{array}$ \\
\hline $\mathrm{B}$ & $0.42+/-0.01$ & $\mathrm{Nb}$ & $0.17+/-0.01$ \\
$\mathrm{Ti}$ & $0.24+/-0.02$ & $\mathrm{Mo}$ & $0.10+/-0.01$ \\
$\mathrm{~V}$ & $0.50+/-0.02$ & $\mathrm{Pd}$ & $0.57+/-0.01$ \\
$\mathrm{Cr}$ & $0.18+/-0.01$ & $\mathrm{Sn}$ & $1.49+/-0.01$ \\
$\mathrm{Mn}$ & $0.37+/-0.01$ & $\mathrm{Cd}$ & $2.76+/-0.02$ \\
$\mathrm{Fe}$ & $25.10+/-0.10$ & $\mathrm{Sb}$ & $2.85+/-0.01$ \\
$\mathrm{Co}$ & $0.38+/-0.01$ & $\mathrm{~Pb}$ & $1.57+/-0.01$ \\
$\mathrm{Ni}$ & $4.46+/-0.11$ & $\mathrm{Bi}$ & $0.14+/-0.01$ \\
$\mathrm{Cu}$ & $1.44+/-0.11$ & $\mathrm{Th}$ & $1.51+/-0.01$ \\
$\mathrm{Zn}$ & $1.13+/-0.01$ & $\mathrm{U}$ & $2.92+/-0.01$ \\
$\mathrm{Sr}$ & $0.09+/-0.01$ & & \\
\hline
\end{tabular}


Queiroz et al, It is used the technique of strong cationic exchange resin, proper to watertreatment, to the neodymium's fractionation and it is achieved a purity of $99.9 \%$ in $\mathrm{Nd} 2 \mathrm{O} 3$ and yield greater than or equal $80 \%$, with the elution of rare earths by EDTA solution in pH controlled [19].

Kuzníková et al describes the preparation of gadolinium oxide nanocrystallites (nano Gd2O3) through thermal decomposition of a complex formed by Gd (NO3)3.6 H2O and glycine [20].

Table 5: Elemental and water assay for the samarium compound Sm (Ac)3. 4H2O [14]

\begin{tabular}{ccccccc}
\hline Compound & \multicolumn{3}{c}{ Calculated (\%) } & \multicolumn{3}{c}{ Exp rimental (\%) } \\
& $\mathrm{C}$ & $\mathrm{H}$ & $\mathrm{Sm}$ & $\mathrm{C}$ & $\mathrm{H}$ & $\mathrm{Sm}$ \\
$\mathrm{Sm}(\mathrm{Ac})_{3} .4 \mathrm{H}_{2} \mathrm{O}$ & 18.04 & 4.28 & 37.63 & 18.00 & 4.30 & 37.50 \\
& & & & & &
\end{tabular}

Table 6: Elemental analyses of $\mathrm{C}, \mathrm{H}$ and $\mathrm{Sm}$ for the samarium acetate prepared [14]

\begin{tabular}{|c|c|c|}
\hline \multirow[t]{2}{*}{$\mathrm{Sm}(\mathrm{Ac})_{3} \cdot 4 \mathrm{H}_{2} \mathrm{O}$} & $\begin{array}{c}\mathrm{H}_{2} \mathrm{O} \\
\text { Calculated }(\%) \text { - Experimental }(\%)\end{array}$ & $\begin{array}{c}\text { Atmosphere } \\
\mathrm{N}_{2}\end{array}$ \\
\hline & 18.03 & \\
\hline
\end{tabular}




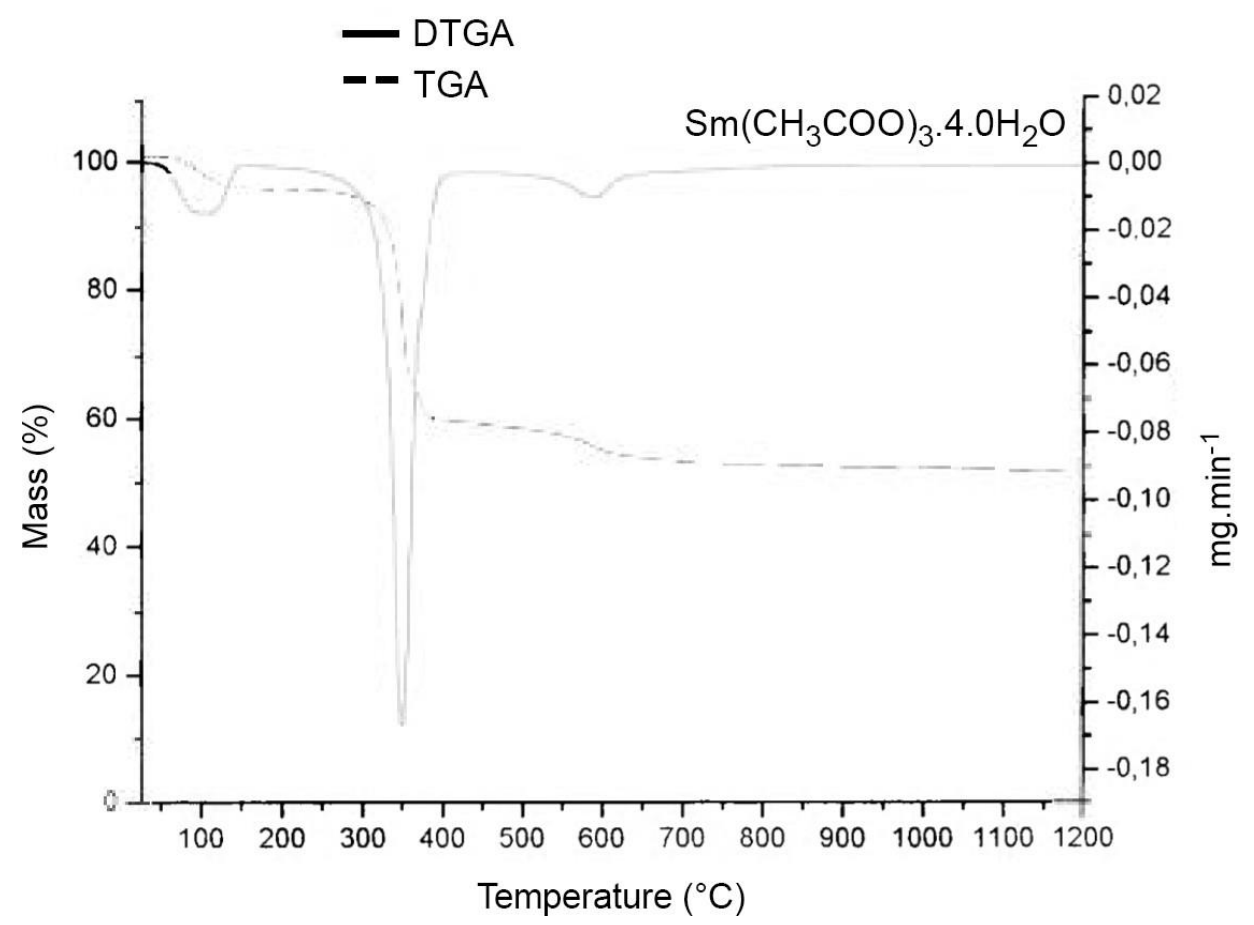

Figure 2: TG/ DTG of the samarium acetate prepared $\mathrm{Sm}\left(\mathrm{CH}_{3} \mathrm{COO}\right)_{3} \cdot 4 . \mathrm{H}_{2} \mathrm{O}$

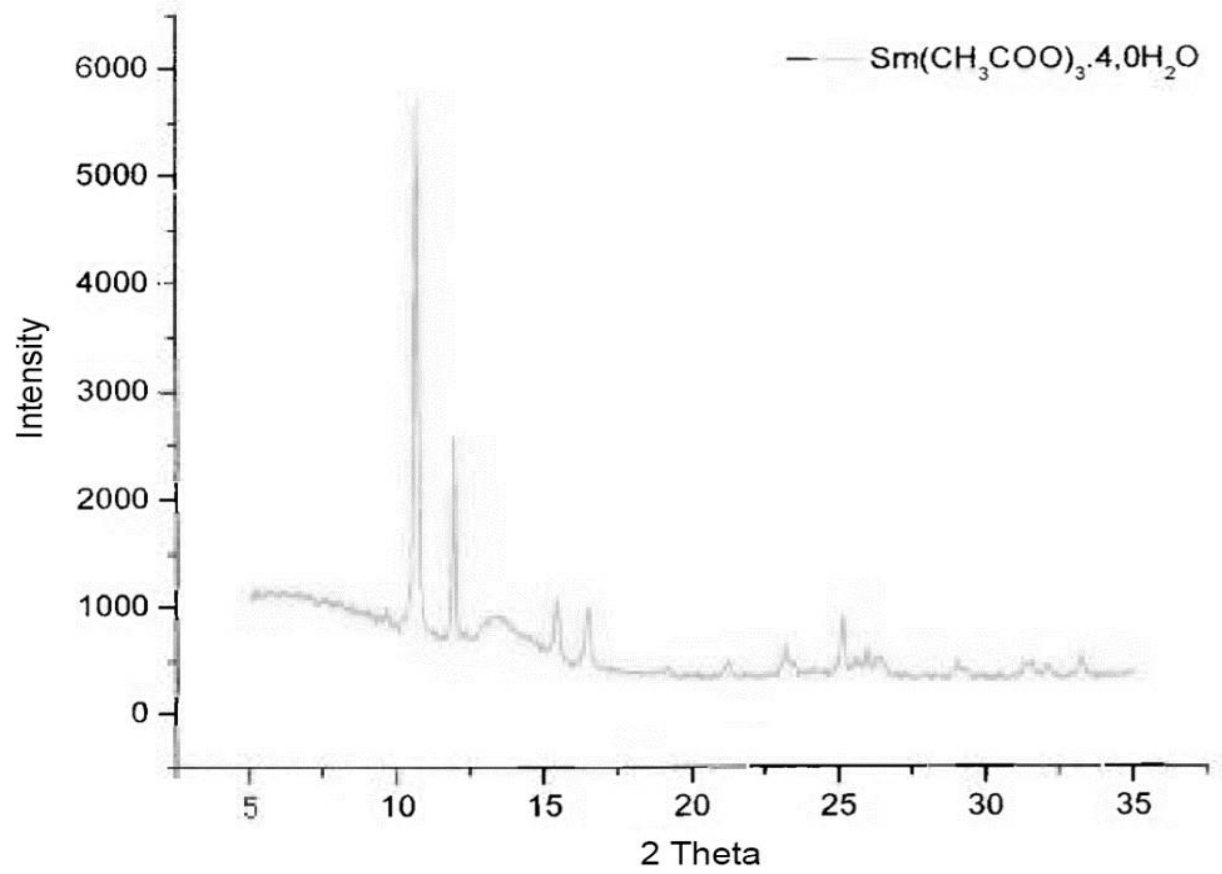


Figure 3: X ray diffractogram of the prepared samarium acetate [14]

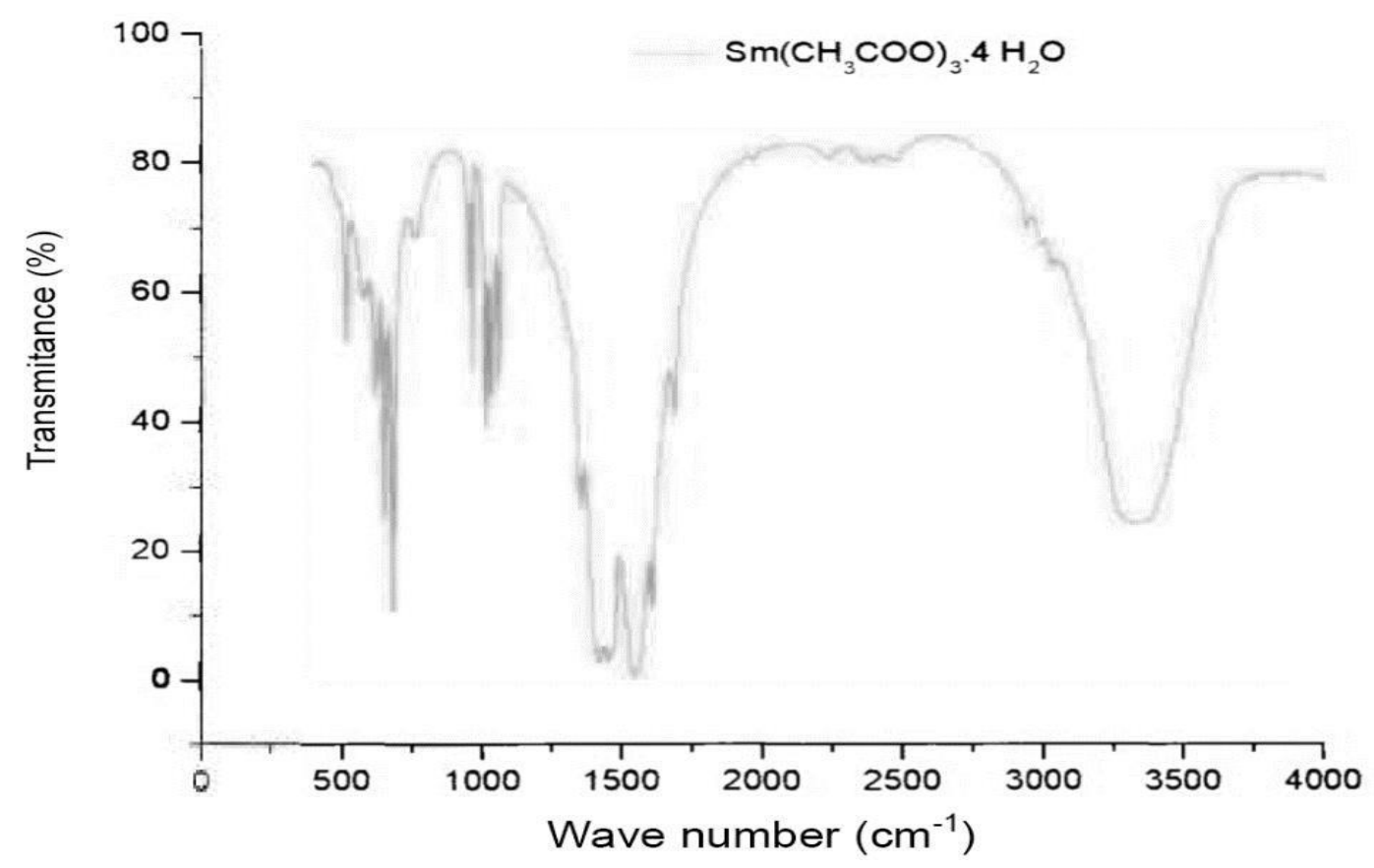

Figure 4: Infrared spectroscopy of the samarium acetate prepared [14]

\section{CONCLUSIONS}

The analytical date collected here (stage 3: Table III, Table IV, Table V, Figure 2, Figure 3 and Figure 4) for the crystallized samarium acetate led to the conclusion that the samarium acetate obtained exhibit the analogous chemical composition published by the technical literature (14).

A simple and economical procedure based on ion exchange, using common cationic ion exchange resins and avoiding the barrier ion, it was possible to prepare high pure samarium oxide and in sequence high pure samarium acetate. The high-purity samarium acetate $(<99.99)$ produced in the present study can be used as an alternative to imported products in research and development applications. The typical $\mathrm{Sm}(\mathrm{CH} 3 \mathrm{COO}) 3.4 .0 \mathrm{H} 2 \mathrm{O}$ prepared contain the followings ra- 
re earths contaminants in micrograms per gram: Y(0.9), Sc (5.1), La (1.0), Pr (3.4), Sm (12.8), Eu (1.1), Gd (15.4), Tb (2.9), Dy (5.3), Ho (7.4), Er(1.5), Tm (0.3), Yb( 2.5), Lu (1.0).

\section{REFERENCES}

[1] Abrão. A. "Química e tecnologia das terras raras”. Série: Tecnologia Mineral n.66. CETEM, Rio de Janeiro, Brasil (1994).

[2] Vieira. E.V.; Lins. F.F. “Concentração de minérios de terras raras”. Série: Tecnologia Mineral n.73. CETEM, Rio de Janeiro, Brazil (1997).

[3] Queiroz. C. A. S.; Abrão. A. "Separação de cério e fracionamento das terras raras a partir dos cloretos mistos". "Química dos lantanídeos e actinídeos", ACIESP 36, São Paulo, SP, Brazil, 1982, p.200-224 (1982).

[4] Queiroz. C. A. S.; Abrão. A. “Obtenção de neodímio e lantânio de alta pureza a partir de uma mistura de cloretos de terras raras". "Química dos lantanídeos e actinídeos", ACIESP 44, vol.1, São Paulo, SP, Brazil, 1984, p.57-75 (1984).

[5] Queiroz. C. A. S.; Abrão. A. Obtenção de gadolínio e samário puros a partir de uma mistura de carbonatos de terras raras por troca iônica. "Química dos lantanídeos e actinídeos", ACIESP 50, vol.1, São Paulo, SP, Brazil, 1986, p.33-45 (1986).

[6] Queiroz. C. A. S.; Abrão. A. “Alguns aspectos do controle analítico aplicado ao processo de separação das terras raras". Química dos lantanídeos e actinídeos”, ACIESP 68, vol.1, São Paulo, SP, Brazil, 1990, p.157-189 (1990).

[7] Reino, L.C.P. e Lordello, A. R. "Determinação de elementos lantanídicos em óxidos de lantânio, de samário e de gadolínio por espectrometria de emissão com plasma”. IPEN-317 (1990).

[8] Pedreira. W. R.; Queiroz. C. A. S.; Abrão. A. and Pimentel. M. M. "Quantification of trace amounts of rare earth elements in high purity gadolinium oxide by sector field inductively coupled plasma mass spectrometry (ICP-MS)". Journal Alloys and Comp..374. pp.129- 132. (2004).

[9] Queiroz. C. A. S.; Vasconcellos. M. E.; Rocha. S. M. R.; Seneda. J. A.; Pedreira. W. R.; Matos. J. R.; Abrão. A. "Synthesis and thermo-analytical characterization of samarium peroxicarbonate” Journal Alloys and Comp..374. pp.401-404 (2004). 
[10] Vasconcellos. M. E.; Queiroz. C. A. S.; Abrão. A. "Sequential separation of the yttrium-heavy rare earths by fractional hydroxide precipitation“ Journal Alloys Comp..374 p. 405 407 (2004).

[11] Vasconcellos. M.E.; Rocha. S. M. R.; Queiroz. C. A. S.; Abrão. A.. "Solubility behavior of rare earths with ammonium carbonate and ammonium carbonate plus ammonium hydroxide: Precipitation of their peroxi-carbonates" Journal Alloys and Comp..451. pp. 426-428 (2008).

[12] Rocha. S. M. R.; Queiroz. C. A. S.; Lobo. R. M.; Forbicini. C. A. L.G. de O.; Seneda. J.A. e Pedreira Filho.W.R.. "Influência do lantânio na estabilidade térmica de aluminas". XVIII CEBCIMAT, 2008, pp. 544-549 (2008).

[13] Pedreira Filho. W. R.; Sarkis. J. E. S.; Queiroz. C. A. S.; Rodrigues. C.; Tomiyoshi.

I. A. and Abrão. A. "Determination of trace amounts of rare-earth elements in highly pure neodymium oxide by sector field inductively coupled plasma mass spectrometry (ICP-SFSM) and high-performance liquid cromatography (HPLC) technique". Journal of Solid State Chemistry, 171 (1): pp. 3-6. (2003).

[14] Rocha. S.M.R. "Síntese e caracterização de precursores para catalisadores termicamente estáveis à base de lantanídeos pelo método sol-gel". Tese de doutorado apresentada ao IPEN/CNEN/SP (2008).

[15] Rocha. S.M.R. et al "Influência do lantânio na estabilidade térmica de aluminas", XVIII CEBCIMAT, 2008, 544-549 (2008).

[16] Pedreira Filho. W.R. "Determinação de impurezas metálicas em óxidos de terras raras de alta pureza pela espectrometria de massa (setor magnético) com fonte de plasma induzida por argônio (HR-ICP-MS) e cromatografia líquida de alto desempenho (HPLC)". Tese de doutorado apresentada ao IPEN/CNEN/SP (2000).

[17] Queiroz, C.A.S. “Terras raras: obtenção de padrões espectro-químicos, estudo dos carbonatos e síntese dos peroxicarbonatos - uma nova série de compostos". Tese de doutorado apresentada ao IQ/USP/SP (1996).

[18] Queiroz. C. A. S.; Pedreira Filho. W. R. and Seneda. J. A. "Preparation of high purity neodymium oxide from Brazilian monazite by ion exchange”. Journal of Energy and Power Engineering. 9, 616-621 (2015). 
[19] Queiroz. C. A. S.; Pedreira Filho. W. R. and Seneda "Preparation of neodymium acetate for use in nuclear area and nanotechnology", 2017 International Nuclear Atlantic Conference, INAC, 2017.

[20] L. Kuzníková, K. Dědková, L. Pavelek, J. Kupková, R. Váňa, M. H. Rümmeli and J.

Kukutschová, Synthesis and Characterization of Gadolinium Oxide Nanocrystallites, In book: Proceedings of the 2nd Czech-China Scientific Conference 2016. 